\title{
Anthropological foundation of environmental science
}

\author{
Rozaliya Rupova ${ }^{1, *}$ \\ ${ }^{1}$ Russian State Social University, st. Wilhelm Pick, Building 4, p. 1, 129226, Moscow, Russia
}

\begin{abstract}
The author of the article notes the obvious contradiction of our time, which consists in the fact that the rapid development of technology is combined with an increase in political tension, escalation of violence, and an eschatological feeling of extreme depletion of environmental and civilizational resources. This testifies to the crisis state of civilization, which can be more accurately described as a crisis of man himself. Based on the principle of the interdependence of anthropology and culture, the author proposes to include in the orbit of theological understanding not only the social and humanitarian sphere of civilization life, but also natural science, as well as the technosphere. The article proposes a variant of the classification of traditions and methods of broadcasting their content, which makes it possible to look at science as part of a cultural tradition that builds relationships with a spiritual tradition as a core one. But, first of all, the structuring of traditions in society makes it possible to clearly see their hierarchy and mutual influences. Especially valuable is the isolation of the spiritual tradition and the separation of the religious from it. This provides a key to understanding many processes in the history of civilization - in the sphere of religious life, in culture, in socio-political processes. Traditions such as religious, cultural and social build their own relationships with spiritual tradition. The forms of these relations create a multidimensional characteristic of the state of society in a given historical period.
\end{abstract}

\section{Introduction}

The obvious contradiction of our time is that the rapid development of technology, which makes it possible to improve, it would seem, to the limit, means of communication, build fancy skyscrapers, multi-level transport systems, create functional analogs of human organs in medicine, and much more - on the one hand - is combined with an increase in political tension, an escalation of violence, an eschatological sense of the extreme depletion of ecological and civilizational resources. This indicates a crisis state of civilization, which, however, is not something new. The twentieth century with its revolutions and world wars was unambiguously diagnosed as a crisis, and the crisis itself was characterized as anthropological, that is, the crisis of the person himself. Now he has crossed the millennium line. The study of the way of the formation of European culture allows, according to the Parmenidean principle of the unity of the historical and the logical, to clearly see and

\footnotetext{
${ }^{*}$ Corresponding author: centermarx@yandex.ru
} 
comprehend the generating factors of the current anthropological crisis situation, as well, therefore, as the whole sociocultural picture. Metaphorically speaking, to heal a patient, you need to know the history of the disease.

\section{Materials and methods}

Consideration of individual eras with their characteristic anthropology in our approach is based on the principle of interdependence of culture and anthropology. "Style is a man" ("Style est homo") - this is the statement of the French naturalist Georges Buffon (17071788) from a speech made on August 25, 1763 when he was elected a member of the French Academy [1]. Over the past centuries the statement has overgrown with unexpected

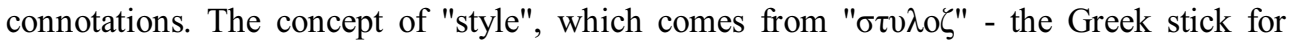
writing - goes back in etymological chain to $\sigma \tau \hat{\eta} \lambda \eta$ - a column, a stele, which is important in archaic cultures: - laws, treaties were written on it, it could be a border or pillar of shame. One way or another, he established certain boundaries - cult, legal, semantic, which was of decisive importance in society. Thus, if we return to the word "style", which is now understood exclusively in the system of aesthetic characteristics as "a set of features, the proximity of expressive artistic techniques and means that condition the unity of some direction in creativity ..." the meaning that it lost, then one can reach a very important and productive generalizations. Thus, the concept of style deepens to the roots of culture, and, therefore, to the theme of a cult. Taking this into account, the study of any, without exception, culture in the history of mankind allows us to see its anthropological roots, a direct connection between the dominant doctrine of man, which is most often not expressed, implicitly, and the whole array of cultural forms corresponding to a given era. So, culture always leads us to anthropology. But the opposite is also true: this or that anthropology determines the basic codes of culture, its matrix.

Among the many definitions of culture, there is one given in the authoritative study of V.S. Stepin. and his coauthors: "culture is a system of social relay races in which participants pass on role models to each other." [2] The function of transferring, broadcasting some meaningful content is a characteristic feature of tradition, which can be opposed to the chaos and polyphony of cultural forms. This concept, which is also quite vague, allows, however, a systematic look at the processes taking place in society.

Etymological reading of the word "tradition": traditio or tradition (transmission), as pointed out by S.S. Horuzhy, allows us to see as the main one - the transmission mechanism, as "a transmitting mechanism in historical time and in human society, as a social or cultural institution, that carrying out storage and transmission, broadcasting of some fund, heritage, values, attitudes, etc". [3] This key mechanism forms the connecting basis of the entire historical process.

\section{Results}

Let us consider in these coordinates the spiritual tradition of Christianity. The content she broadcasts is the event of Christ in the fullness of his mission and teaching, accumulated in the mystical-ascetic experience of the Eastern Church. The leading way of broadcasting is "from mentor to student" in the process of personal communication. Spiritual tradition, according to the authoritative scientific research of S.S. Horuzhy, is "a personal, energetic, anthropological phenomenon" [4]. Its uniqueness is manifested in the fact that without creative efforts its preservation and transmission are impossible. Maintaining the identity of spiritual experience during epochs so far apart from each other in time, radically different in the mentality of culture, anthropological realities, is possible exclusively creatively. Around 
the spiritual tradition, as a broader one, a religious tradition is built. The broadcast content is much more diverse and variegated - these are both material forms of worship, and institutional structures and religious behavioral stereotypes. The way of broadcasting is also very diverse - through ritual forms, religious institutions. And although spiritual practice is the core of a religious tradition, by its very nature a religious tradition is a social phenomenon.

The cultural tradition that follows it can be considered as a vast complex of traditions with different content and ways of transmission. These are "cultural monuments", scientific, professional and philosophical schools, a set of art forms, ethical norms, etc. Broadcasting methods are mainly institutional and collective. Cultural tradition is inherently a social phenomenon. It can be associated with a spiritual tradition, be guided by it, act as an adjoining one. Scientific knowledge, also in the form of tradition, is part of the cultural tradition. Thus, we can present the history of European civilization as a multilevel dynamic system, a process. The leading deep stream, the mainstream in it is the spiritual tradition of Christianity. Religious, then cultural, and the broadest social tradition, which defines social institutions as such, is built around it (Fig. 1). The interweaving of all these traditions form the historical life of society. Each of the traditions is anthropocentric in a specific way, that is, it codifies its own special kind of anthropological identity. At the same time, spiritual tradition occupies an exceptional position among others, since, unlike them, it builds a person's relationship to otherness. Identity, proclaimed by the spiritual tradition of Christianity, is determined by the theocentric anthropological paradigm, conditioned by the fact of man's creation "in the image and likeness of God."

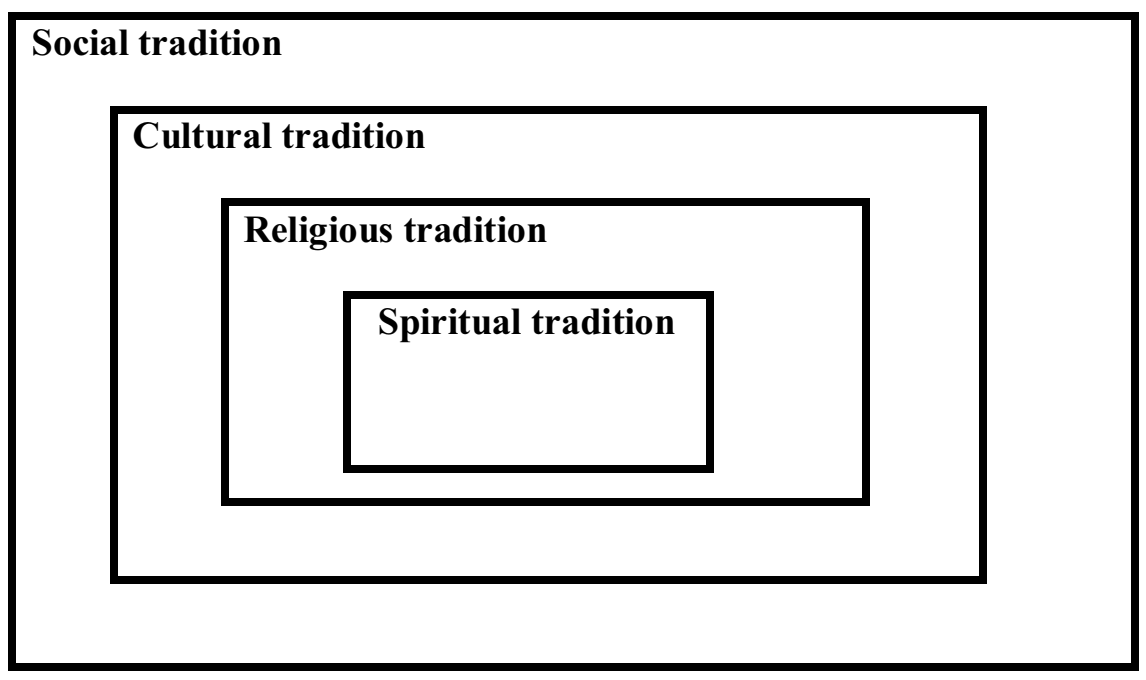

Fig. 1. An ensemble of traditions in society.

In other traditions, identity is built in connection with certain sociocultural forms that belong to the earthly horizon of being. Therefore, in these traditions a person is reduce, exposing him, for example, as a social subject.

There are epochs in history when the spiritual tradition of Christianity had a colossal and leading influence on the life of society - the entire Byzantine period, the European Middle Ages, pre-Petrine Russia. In other periods, she influenced society more indirectly, through various socio-anthropological practices. In this case, the spiritual tradition, as focused on personal experience and building ontologically stronger relationships - the relationship between man and God, affecting the deep spheres of human existence, acts as a leading one, and another (for example, a cultural tradition) - as an adjoining one - not always in its entirety, 
possibly in the person of individual schools and directions. The relationship of traditions has a value of a very important characteristic of society.

Table 1. Ways of broadcasting.

\begin{tabular}{|c|c|c|c|}
\hline 1. & Tradition & Broadcast content & Broadcast method \\
\hline 2. & Spiritual tradition & $\begin{array}{c}\text { the event of Christ in } \\
\text { the fullness of His } \\
\text { mission and teaching }\end{array}$ & from mentor to student \\
\hline Religious tradition & $\begin{array}{c}\text { material and } \\
\text { institutional forms of } \\
\text { worship, religious } \\
\text { behavioral } \\
\text { stereotypes }\end{array}$ & $\begin{array}{c}\text { "Cultural } \\
\text { monuments", } \\
\text { scientific, } \\
\text { throfessional and } \\
\text { religious institutions } \\
\text { philosophical schools, } \\
\text { a set of art forms, } \\
\text { ethical norms, etc. }\end{array}$ & $\begin{array}{c}\text { mainly institutional and } \\
\text { collective forms and } \\
\text { methods of broadcasting }\end{array}$ \\
\hline 4. & Cultural tradition & Social tradition & social institutions \\
\hline
\end{tabular}

The structuring of traditions in society, as follows from the above examples, allows you to clearly see their hierarchy and mutual influences. It is especially important to single out the spiritual tradition and to separate the religious from it. The separation of these very traditions provides the key to understanding many processes in the history of civilization - in the sphere of religious life, in culture, in socio-political processes. As we can see, traditions such as religious, cultural and social build their own relationship with the spiritual tradition. The forms of these relations create a multidimensional characteristic of the state of society in a given historical period (Table 1).

As has been shown, in the Middle Ages, the cultural tradition was adjacent and even subordinate to the religious tradition. In the Renaissance, they come into conflict and, without breaking with religious tradition, the cultural tradition ceases to be adjacent to the spiritual, breaks with it. In new age, the spiritual tradition is being pushed to the periphery of social life, and the cultural tradition becomes dominant. During this period, a remarkable transformation of theology took place in the West. It also loses its connection with the spiritual tradition, continuing to exist in the education system as a science, that is, as part of a cultural tradition.

Singling out science as part of a cultural tradition, one can see that it, like culture as a whole, builds its relationship with the spiritual tradition. Approaching the basic meanings of the spiritual tradition, or moving away and denying it, science in its historical forms, nevertheless, is in dialogue with it. This dialogue between science and spiritual tradition is reflected in the writings of the following authors: Horuzhy S.S. [5], Legeev M.V., Zinkovsky S.A., Zinkovsky E.A. [6], Nesteruk A.V. [7], Chul Min Jun [8].

\section{Discussion}

The anthropological turn of the twentieth century, which was a consequence of the anthropological crisis, brought a person into the focus of attention of the entire complex of sciences. Even theological discourse has been anthropologized - it is based on the understanding of man as a being in principle open to the Absolute and contains the potential for theological comprehension of culture. The process of this understanding is carried out in 
the works of many researchers: Zinkovsky M. [9], Mikhailov P.B. [10], Solonchenko A.A. [11], Mahler A.M. [12], Fufaev S. [13], Rupova R.M. [14] and in her other study on this topic [15].

However, it cannot be complete when the sphere of natural science is removed from it.

The above-mentioned modern, pronounced anthropological perspective opens up the possibility of an anthropological reading of natural science. The next step may be a theological analysis. Thus, the theological understanding of natural science is possible, in general, not directly, through the analysis of certain scientific theories and inventions, but through its anthropological basis. Man, as the master of the world, has created an amazingly complex civilization. If we look around, we will see already new generations of bizarre skyscrapers (and not just very tall buildings), which, with their spirals, seem to challenge all wind roses and theories of material resistance. We will see rings of multi-level transport systems, modern technologies, amazing means of communication, etc. It would seem, what could be better, more interesting and more reliable in the world? But something went wrong. A person in the middle of this world feels defenseless and anxious. Technotronic civilization, instead of protecting its creator and serving him, rebelles, becomes a source of unprecedented risks and carries wich it threats directly proportional to its power. That is why there is an urgent need for a humanitarian analysis of the non-humanitarian civilizational sphere. And theology should become the core of such an analysis, due to its belonging to the spiritual tradition, which is the core of culture.

For example, let us take one of the eras in the history of European culture - Baroque which unfolded in the time interval from the beginning of the 17th to the middle of the 18th centuries and which became the basic stage in the formation of modern science. We can say that this era carried out further development of the ideas of Renaissance anthropocentrism and humanism. Let's make an amendment: the time of troubles of a relatively short postRenaissance era of Mannerism - a time of severe upheavals for Europe associated with the movement of the Reformation that "cut off the wings of Icarus", showed man's dependence on existential factors and laws of nature and reduced the boundless rise of the Renaissance. Of the many abilities of human nature, reason comes first, manifested in the winged formula "cogito ergo sum". The defining feature of the Baroque era is the confidence in the possibility of rational knowledge of nature and its reconstruction on the basis of reasonable principles. In the 17th century, a mechanistic scientific picture of the world was formed, in which the claims of reason to master the keys of the world order were expressed. The clockwork, created and wound up by the Master (God) and handed over to users - with its fine-tuned causal relationship, has become the most accurate symbol of the world order.

This picture of the world had its own prominent anthropological connotations. They were most clearly expressed in one of the directions of Cartesianism. Le Roy (Henri Leroy, 15981679) - a representative of the extreme mechanistic approach in anthropology - developed a mechanistic view of the human body. He denied mental processes in man, reducing them to physical ones. La Mettrie (Julien Offray de La Mettrie 1709-1751), influenced by Cartesian ideas, wrote the book Man-Machine, in which man is described as a purely mechanical system, a self-winding machine. According to this view, a person, unlike an animal, has a soul, from which his body is autonomous. All processes in a person are subject to cause-andeffect relationships, which do not depend either on a mental impulse, or on free will or other manifestations of spiritual substance. Absolutely everything in him is a consequence of his materiality: emotions, thoughts, and desires. This doctrine can be called the apotheosis of the baroque mechanistic rationalism that swept over anthropology. Such a consistent presentation of the materialistic concept of man will subsequently be developed by many scientists, and especially psychologists in the twentieth century (Z. Freud). 
Morality in this system is a far-fetched concept, no less a prejudice than conscience, from the remorse of which one must free oneself: the main criterion of happiness for a person is sensual pleasure.

It can be seen that the Baroque era deepened the break with the spiritual tradition - the break that was started by Western European culture, - while remaining in line with the religious tradition. This is obvious from the fact that the basic principles of the new science followed from the biblical interpretation of God as the Creator and Lawgiver of nature, who entrusted the world to Adam for its cultivation and transformation, as well as from the very terminology using the language of Christian discourse. Archpriest Georgy Florovsky, the creator of the neo-patristic synthesis, positioned theology as a universal, without exception, way of considering all aspects of culture: "In essence, our attitude to culture is not a practical choice, but a theological position from beginning to end." [16]. In his work "Justification of Knowledge" [17] he asserts: "Liberation of certain areas of life from the complete churching is in the latter case, removing them from religious testing and observation, leaving them at liberty at the mercy of untransformed, unsanctified natural forces. In this reality there is a rejection of the sanctification and transformation of the world ". Archpriest Georgy Florovsky notes the continuing situation of choice facing each individual and the historical Church: "We still face the same dilemma. Or Christians must leave the world, in which, besides Christ, there is another master ... and create a separate society. Or they again need to transform the outside world and rebuild in accordance with the law of the Gospel". The language of patristic theology can become the matrix that will open up the possibility of modern culture to comprehend itself in the coordinates of Christian axiology. And not only to comprehend. Christianity, which literally saved the ancient civilization from destruction, breathing new life-giving meanings and forces into it, has the resource to repeat this mission in history. But this can happen not "by itself", but through the application of maximum creative efforts on the part of Christians who are aware of their responsibility for the fate of civilization.

\section{References}

1. Dictionary of winged words and expressions. URL: http://dic.academic.ru/dic.nsf/dic_wingwords/2616 (date of the application 27.02.2021)

2. V.S. Stepin, V.G. Gorokhov, M.A. Rozov, Philosophy of Science and Technology (Moscow, 1996)

3. S.S. Horuzhy, Experiments from the Russian spiritual tradition (Moscow: St. Thomas, 2018) URL: http://esxatos.com/horuzhiy-opyty-iz-russkoy-duhovnoy-tradicii (date of the application 27.02.2021)

4. S.S. Horuzhy, Cosmic liturgy as ecological principle of orthodox culture, Philosophy and Culture 2, 268 - 274 (2016) https://doi.org/10.7256/1999-2793.2016.2.16982

5. M.V. Legeev, S.A. Zinkovsky, E.A. Zinkovsky, The Scientific and Teological Interpretation of History in the 4th - 5th Centuries: Atempts and Tendencies, Christian reading 4, 10-27 (2018) DOI: 10.24411/1814-5574-2018-10078

6. A.V. Nesteruk, From a neo-patristic legacy of Georges Florovsky to the radical theological commitment in the dialogue with science, Journal of the Siberian Federal University. Series: Humanities 9, 9, 2150-2183 (2016) DOI: 10.17516/1997-1370-20169-9-2150-2183

7. C.M. Jun, The paradigm shift of practical theology and theological practice to overcome modernism and postmodernism, Pacific Science Review 16, 156-166 (2014) https://doi.org/10.1016/j.pscr.2014.08.028 
8. M. Zinkovsky, Hesikhasm and the diversity of the person, Person 2, 148-154 (2018) DOI: $10.7868 / \mathrm{S} 0236200718020128$

9. P.B. Mikhailov, The concept of the Hellenization of Christianity in the history of theology, Bulletin of the Orthodox St. Tikhon Humanitarian University. Series 1: Theology. Philosophy. Religious studies 71, 50-68 (2017) DOI: $10.15382 /$ sturI201771.50-68

10. A.A. Solonchenko, Trinity personalism of S.N. Bulgakov: concept of love, monarchy of the Father and the Trinity, Social policy and sociology 17, 3 (128), 119-125 (2018) DOI: 10.17922/2071-3665-2018-17-3-119-125

11. A.M. Mahler, Concept of personality in secular and post-secular understanding, Notebooks on conservatism 3, 131-138 (2019) DOI: 10.24030/24092517-2019-0-3-131$\underline{138}$

12. S. Fufaev, Interpretation of V.N. Losskiy dogmatic concepts " hypostasis" and "Individual", Theological Bulletin 35, 4, 38-71 (2019) DOI: 10.31802/2500-1450-2019$\underline{\text { 35-38-71 }}$

13. R.M. Rupova, Bogoslovsky anthropology and modern scientific knowledge: dialogue on rights to the role of metadiscursion, Social policy and sociology 17, 2 (127), 186-193 (2018) https://doi.org/10.17922/2071-3665-2018-17-2-186-193

14. R.M. Rupova, Man in reflection of the orthodox theology: tradition and its modern measurements, Social policy and sociology 17, 3 (128), 111-118 (2018) DOI: $10.17922 / 2071-3665-2018-17-3-111-118$

15. G.V. Florovsky, Faith and culture (SPb., 2002) URL: http://www.odinblago.ru/pravoslavie/flor2/(date of the application 27.02.2021)

16. G. Florovsky, Justification of knowledge (SPb.: Publishing house of the RKhGA, 2002) URL: http://www.odinblago.ru/pravoslavie/flor2/(date of the application 28.02.2021)

17. R.M. Rupova, Neopatristic Synthesis as a Religious and Philosophical Current of the XX-XXI Centuries: Religious-Anthropological Analysis. Dissertation for the degree of Doctor of Philosophy. $\quad 32 . \quad$ URL: https://www.dissercat.com/content/neopatristicheskii-sintez-kak-religioznofilosofskoe-techenie-xx-xxi-vekov-religiovedchesko- (date of the application 28.02.2021) 